\title{
ANALISIS EFEKTIVITAS PENERIMAAN RETRIBUSI PENGUJIAN KENDARAAN BERMOTOR DI KABUPATEN PONOROGO
}

\author{
Purweni Widhianningrum ${ }^{1)}$, Sasongko Aji ${ }^{2)}$ \\ Fakultas Ekonomi dan Bisnis Universitas PGRI Madiun \\ email: wenitugas@ gmail.com ${ }^{1)}, \underline{\text { Sasongkoaji93@gmail.co.id }}{ }^{2)}$
}

\begin{abstract}
This study aims to determine the effectiveness of the acceptance of motor vehicle testing levies in Ponorogo Regency in 2014-2018. Data collection techniques using primary and secondary data through interviews, observation and documentation. Data testing is done by effectiveness ratio. The results showed that the effectiveness of the acceptance of motor vehicle testing levies over the past five years was fluctuating, overall quite effective because it was less than 100\%, it needed a socialization given by the government to the public that safety in driving was very important. Improving the staffing of levies collection staff to improve the process of levies collection to be optimal and increasing supervision to know whether the implementation of activities in the field in accordance with the provisions, as well as improving administrative efficiency and reduce the cost of collection.
\end{abstract}

Keywords: Effectiveness, PAD, Motorized Vehicle Testing Levies.

\begin{abstract}
Abstrak
Penelitian ini bertujuan untuk mengetahui efektivitas penerimaan retribusi pengujian kendaraan bermotor di Kabupaten Ponorogo pada tahun 2014-2018. Teknik pengumpulan data menggunakan data primer dan sekunder yaitu melalui wawancara, observasi dan dokumentasi. Pengujian data dilakukan dengan rasio efektivitas. Hasil penelitian menunjukkan bahwa efektivitas penerimaan retribusi pengujian kendaraan bermotor selama lima tahun terakhir adalah fluktuatif, secara keseluruhan cukup efektif karena kurang dari 100\%, diperlukan adanya sosialisasi yang diberikan pemerintah kepada masyarakat bahwa keselamatan dalam berkendara sangat penting. Memperbaiki SDM Staf pemungutan retribusi agar memperbaiki proses pemungutan retribusi agar optimal, dan meningkatkan pengawasan untuk mengatahui apakah kegiatan pelaksanaan di lapangan sesuai dengan ketentuan, serta meningkatkan efisiensi administrasi dan menekan biaya pemungutan.
\end{abstract}

Kata Kunci: Efektivitas, PAD, Retribusi Pengujian Kendaraan Bermotor

\section{PENDAHULUAN}

Pelaksanaan desentralisasi fiskal di era reformasi secara resmi dimulai sejak 1 Januari 2001, delapan belas tahun sudah usia implementasi otonomi daerah dan desentralissasi fiskal di indonesia. Untuk menyelaraskan dengan perkembangan keadaan, ketatanegaraan, dan tuntutan penyelenggaraan pemerintah daerah, peraturan mengenai otonomi daerah dan desentralisasi fiskal di indonesia senantiasa mengalami perubahan (Nugraha, 2019:1).

Otonomi daerah dan desentralisasi fiskal di indonesia terakhir diatur dengan Undang-Undang No. 2 Tahun 2015 tentang perubahan kedua atas UndangUndang No. 23 Tahun 2014 tentang Pemerintah Daerah, serta UU No. 33
Tahun 2004 tentang Perimbangan Keuangan antara Pemerintah Pusat dan Pemerintah Daerah. Menurut Sari (2016:1) penyelenggaraan otonomi daerah oleh pemerintah pusat bertujuan untuk meningkatkan pelayanan publik dan demi memajukan perekonomian suatu daerah. Sebagai daerah otonom, daerah berwenang dan bertanggung jawab atas penyelenggaraan kepentingan masyarakat dan bertanggung jawab kepada masyarakat Negara Kesatuan Republik Indonesia sesuai dengan perundang-undangan yang berlaku. Otonomi daerah hendaknya memperbaharui hubungan pemerintah pusat dan pemerintah daerah yaitu melalui perubahan corak hubungan yang semula berada pada azas-azas dekonsentrasi menjadi azas desentralisasi. 


\begin{tabular}{lcr}
\multicolumn{2}{c}{ Pemerintah daerah } & memiliki \\
kewenangan & untuk & melakukan \\
pemungutan & terhadap & pajak-pajak
\end{tabular}
tertentu,melakukan usaha-usaha tertentu untuk mendapatkan sejumlah uang agar dapat membiayai pengeluaran rutin dan pengeluaran pembangunan, membuat peraturan-peraturan daerah yang dibutuhkan dalam menyelenggarakan pemerintah daerah dan berhak untuk memperoleh sejumlah dana yang berupa transfer dari pemerintahan pusat. Berdasarkan UU No. 28 Tahun 2009

Tentang Retribusi Daerah adalah Pungutan Daerah sebagai pembayaran atas jasa atau pemberian izin tertentu yang khusus disediakan dan atau diberikan oleh pemerintah daerah untuk kepentingan orang pribadi atau badan. Retribusi daerah dapat dikelompokkan ke dalam tiga golongan, yaitu retribusi jasa umum, retribusi jasa usaha, dan retribusi perizinan tertentu.

Peraturan Daerah Nomor 14 Tahun 2011 tentang retribusi pengujian kendaraan bermotor adalah serangkaian kegiatan menguji dan atau memeriksa bagian-bagian kendaraan bermotor, kereta gandengan, kereta tempelan, dan kendaraan khusus dalam rangka pemenuhan persyaratan teknis laik jalan. Retribusi kendaraan bermotor merupakan salah satu unsur penting bagi pemerintah daerah dalam meningkatkan jumlah pendapatan daerah guna mendukung pembangunan yang akan terjadi di masa yang akan datang dan untuk membiayai penyelenggaraaan pemerintah daerah dan pembangunan daerah di era sekarang.

Mewujudkan pelaksanaan otonomi daerah sebagai asas desentralisasi pemerintah daerah harus mempunyai sumber-sumber penerimaan atau pendapatan daerah. Pendapatan Asli Daerah (PAD) merupakan pendapatan daerah yang bersumber dari hasil pajak daerah, hasil retribusi daerah, hasil pengelolaan kekayaan daerah yang dipisahkan, dan lain-lain pendapatan asli daerah yang sah, yang bertujuan untuk memberikan keleluasaan kepada daerah dalam menggali pendanaan atau Pendapatan Asli Daerah (PAD) sangat berpengaruh terhadap perkembangan dan kemajuan dalam suatu daerah (UndangUndang No.33 Tahun 2004).

Dinas Pendapatan Daerah Ponorogo dalam mengoptimalkan retribusi daerah dengan dibantu oleh dinas-dinas tertentu, yaitu salah satunya Dinas Perhubungan Kabupaten Ponorogo. Dinas Perhubungan Kabupaten Ponorogo yang setiap peneriman pajak daerah dan retribusi daerah dari setiap dinas akan diserahkan kembali kepada Dinas Pendapatan Daerah. Pelaksanaan pemungutan retribusi Pengujian Kendaraan Bermotor (PKB) belum terlaksana dengan baik, maka pemerintah masih harus melakukan perluasan dalam basis penerimaan.

Menurut

perhubungan.ponorogo.go.id sebanyak 41 Unit Pelaksanaan Uji Kendaraan Bermotor (UPUBKB) berhasil memperoleh akreditasi dari Dirjen perhubungan Darat Kementrian Perhubungan Pemberian Sertifikat Akreditasi disampaikan Sekjen Kemenhub Djoko Sasono dan Ditjen Perhubungan Darat Budi Setiyadi dan Dinas Perhubungan Kabupaten Ponorogo merupakan salah satu dari 41 UPUBKB yang berhasil memperoleh akreditasi, ini seharusnya dapat meningkatkan kepercayaan masyarakat agar setiap angkutan jalan mendapatkan pengujian kendaraan dan memastikan dalam kondisi prima untuk menjaga keselamatan bersama dalam berlalu lintas.

Tarif uji kelayakan atau uji ker kendaraan bermotor di Ponorogo akan segera dinaikkan oleh Dinas Perhubungan setempat. Kenaikan ini dipastikan sebagai cara untuk memutus rantai percaloan yang masih marak akhir-akhir ini. Berdasarkan keputusan Kepala Dinas Perhubungan Kabupaten Ponorogo per 1 Januari 2018 
pihaknya telah bekerjasama dengan Bank Jatim untuk memberikan layanan uji ker secara non tunai. Menurut Djunaidi langkah agar tidak ada biro jasa yang masuk.

Pencapaian realisasi pendapatan retribusi $\mathrm{PKB}$ yang tidak mencapai target dari pemerintah daerah selama tiga tahun terakhir membuat peneliti tertarik untuk melakukan penelitian dengan judul "Analisis Efektivitas Penerimaan Retribusi Pengujian Kendaraan Bermotor di Kabupaten Ponorogo".

\section{KAJIAN PUSTAKA \\ Otonomi Daerah}

Undang-Undang Nomor 28 Tahun 2009 Pasal 1 Daerah Otonom yang selanjutnya disebut daerah, adalah kesatuan masyarakat hukum yang mempunyai batas-batas wilayah yang berwenang mengatur dan mengurus urusan pemerintah dan kepentingan masyarakat setempat menurut prakarsa sendiri berdasarkan aspirasi masyarakat dalam sistem Negara Kesatuan Republik Indonesia. Kewenangan otonomi luas tersebut berupa keleluasaan daerah untuk menyelenggarakan pemerintah yang mencakup kewenangan semua bidang pemerintahan, kecuali kewenangan di dalam politik luar negeri, pertahanan keamanan peradilan,moneter dan fiskal, agama, serta kewenangan bidang lain yang akan ditetapkan dengan peraturan pemerintah. Sedangkan otonomi yang bertanggung jawab merupakan konsekuensi pemberian hak dan kewenangan kepada daerah dalam wujud tugas dan kewajiban yang harus dipikul oleh daerah dalam mencapai tujuan pemberian otonomi berupa peningkatan pelayanan dan kesejahteraan masyarakat yang semakin baik, pengembangan kehidupan demokrasi, keadilan, dan pemerataan, serta memelihara hubungan yang serasi antara pusat dan daerah serta antar daerah dalam rangka menjaga keutuhan Negara Kesatuan Republik Indonesia (Widodo, 2017:2-3).

\section{Penerimaan Asli Daerah (PAD)}

Undang-undang Nomor 33 Tahun 2004 pendapatan asli daerah (PAD) adalah pendapatan yang diperoleh daerah yang dipungut berdasarkan peraturan daerah sesuai dengan peraturan perundang-undangan. PAD bertujuan untuk memberikan kewenangan kepada Pemerintah Daerah untuk mendanai pelaksanaan otonomi daerah sesuai dengan potensi daerah. Sumber pendapatan asli daerah terdiri dari:

a) Pajak daerah

b) Retribusi daerah

c) Bagian laba pengelolaan aset daerah yang dipiahkan

d) Lain-lain PAD yang sah

\section{Retribusi Daerah}

Retribusi daerah adalah pembayaran yang dilakukan oleh masyarakat kepada daerah atas pelayanan yang diterima secara langsung atau atas perizinan yang diperoleh. Berbeda dengan pajak yang dikenakan tidak berdasarkan pelayanan langsung, retribusi hanya dapat dikenakan apabila pemerintah daerah memberikan pelayanan secara langsung kepada masyarakat atau pemerintah daerah memberikan izin untuk melaksanakan kegiatan tertentu (UU No. 34 Tahun 2000), sejalan dengan penjelasan di atas UU No. 28 Tahun 2009 tentang Pajak Daerah dan Retribusi Daerah, sebagai pengganti dari UU No. 18 Tahun 1997 sebagaimana telah diubah dengan UU No. 34 Tahun 2000, lebih mempertegas pengertian retribusi daerah adalah pungutan daerah sebagai pembayaran atas jasa atau pemberian izin tertentu yang khusus disediakan dan diberikan oleh pemerintah daerah untuk kepentingan pribadi atau badan.

\section{Retribusi Kendaraan Bermotor}


Pengujian kendaraan bermotor adalah serangkaian kegiatan menguji atau memeriksa bagian-bagian kendaraan bermotor, kereta gandengan, kereta tempelan dan kendaraan kusus dalam rangka pemenuhan terhadap persyaratan teknis laik jalan (Peraturan Daerah Kabupaten Ponorogo UU Nomor 14 Tahun 2011 Pasal 120). Pembayaran atas pengujian kendaraan bermotor yang disediakan oleh pemerintah daerah. Subjek retribusi PKB meliputi kendaraan mobil penumpang sedang, mobil penumpang jeeb, mobil penumpang minibus, mobil microbus, mobil bus, mobil barang pickup, mobil barang light truck, mobil barang truk, sepeda motor roda dua, sepeda motor roda tiga, dan kendaraan bermotor yang dioperasikan di air. Subjek retribusi kendaraan bermotor adalah orang pribadi atau badan yang menggunkan jasa pengujian kendaraan bermotor (Siregar, 2015:137)

\section{Efektivitas PAD}

Efektivitas adalah kemampuan untuk memilih tujuan-tujuan atau sasaran-sasaran yang tepat dan mencapainya, karena itu efektivitas menunjuk pada kaitan antara output atau apa yang sudah dicapai atau hasil yang sesungguhnya dicapai dengan tujuan atau apa yang sudah ditetapkan dalam rencana atau hasil yang diharapkan. Suatu organisasi dikatan efektif jika output yang dihasilkan bisa memenuhi tujuan yang diharapkan. Fokus pada outcome (hasil) ialah hasil yang telah dicapai dibandingkan hasil yang diharapkan. Jadi, pengukuan efektivitas tidak mungkin bisa dilakukan tanpa mengukur outcome .

Rasio efektivitas menggambarkan kemampuan pemerintah daerah dalam merealisasi pendapatan asli daerah yang direncanakan dibandingkan dengan target yang ditetapkan berdasarkan potensi rill daerah. Semakin tinggi rasio efektivitas, menggambarkan kemampuan daerah yang semakin baik untuk itu pemerintah daerah perlu menghitung secara cermat berapa besarnya biaya yang dikeluarkan untuk merealisasikan seluruh pendapatan yang diterimanya sehingga dapat diketahui apakah pendapatan pemun gutan pendapatannya tersebut efisien atau tidak (Faud, 2016:140).

Mahmudi (2016:141) menyebutkan untuk mengukur kinerja pemerintahan daerah dalam penerimaan pendapatan daerah dapat diukur dengan menggunakan Rasio Efektivitas Pendapatan Asli Daerah (PAD) dengan cara membandingakn realisasi Penerimaan retribusi pengujian kendaraan bermotor dengan target Penerimaan retribusi pengujian kendaraan bermotor (dianggarkan). Rasio ini dirumuskan sebagai berikut:

Rasio Efektivitas $=\frac{\text { Realisasi Penerimaan Retribusi Per Item }}{\text { Target Penerimaan Retribusi Per Item }} \times 100 \%$

Sumber: Mahmudi (2016:141), Faud (2016:140)

\begin{tabular}{ll}
\hline Sangat efektif & $>100 \%$ \\
Efektif & $100 \%$ \\
Cukup Efektif & $90 \%-99 \%$ \\
Kurang Efektif & $75 \%-89 \%$ \\
Tidak Efektif & $<75 \%$ \\
\hline \multicolumn{1}{c}{ Sumber : Mahmudi (2016:141) }
\end{tabular}

\section{METODE PENELITIAN}

Jenis Penelitian

Jenis penelitian ini menggunakan metode penelitian kualitatif. Metode penelitian kualitatif digunakan untuk meneliti pada kondisi objek yang alamiah, (sebagai lawannya adalah eksperimen) dimana peneliti sebagai instrumen kunci, teknik pengumpulan data secara trianggulasi (gabungan), analisis data bersifat induktif/kualitatif, dan hasil penelitian kualitatif lebih menekankan makna dari pada generalisasi (Sugiyono, 2017: 207). Menurut Creswell dalam Sugiyono (2017:206) penelitian kualitatif berarti proses eksplorasi dan memahami makna perilaku individu dan kelompok, menggambarkan masalah sosial atau masalah kemanusiaan, proses penelitian 
mencakup membuat pertanyaan penelitian dan prosedur yang masih bersifat sementara, mengumpulkan data pada setting partisipan, analisis data secara induktif, membangun data yang parsial ke dalam tema, dan selanjutnya memberikan interprestasi terhadap makna suatu data. Kegiatan akhir adalah membuat laporan ke dalam struktur yang fleksibel.

\section{Sumber Data}

Teknik pengambilan data diambil dari sumber-sumber data, yaitu data primer dan data sekunder. Sumber data adalah subjek dari mana data dapat diperoleh. Dilihat dari sumber datanya, maka pengumpulan data dalam penelitian ini menggunakan sumber data primer dan sumber data sekunder. Sumber primer adalah sumber data yang langsung memberikan data kepada pengumpul data, dan data sekunder merupakan sumber yang tidak langsung memberikan data kepada pengumpul data, misalnya lewat orang atau lewat dokumen (Sugiyono, 2013:137).

Data yang digunakan dalam penelitian ini adalah data sekunder. Data sekunder berupa laporan target dan realisasi penerimaan retribusi pengujian kendaraan bermotor Kabupaten Ponorogo tahun 2014-2018 dan jumlah kendaraan bermotor tahun 2014-2018.

\section{Instrumen Penelitian}

Menurut Sugiyono (2017:231) dalam penelitian kualitatif, yang menjadi instrumen atau alat penelitian adalah peneliti itu sendiri. Oleh, karena itu, peneliti sebagai instrumen juga harus "divalidasi" seberapa jauh peneliti kualitatif siap melakukan penelitian yang selanjutnya terjun ke lapangan. Setelah fokus penelitian menjadi jelas maka kemungkinan akan dikembangkan instrumen penelitian sederhana, yang diharapkan dapat melengkapi data dan membandingkan dengan data yang telah ditemukan melalui observasi dan wawancara.Peneliti juga bertindak sebagai perencana, pengumpul data penerimaan retribusi pengujian kendaraan, menganalisisnya, penafsiran data dan peneliti menjadi pelapor hasil penelitiannya serta membuat kesimpulan dan saran. Pengambilan data di lapangan, peneliti dibantu oleh pedoman wawancara, alat rekam dan alat dokumentasi. Hal ini dilakukan untuk memudahkan peneliti dalam pengambilan dan pengumpulan data

\section{Teknik Pengumpulan Data}

Teknik pengambilan data yang digunakan dalam penelitian ini adalah wawancara dan dokumentasi, wawancara yaitu komunukasi langsung yang dilakukan peneliti kepada Kepala Bagian Retribusi Pengujian Pendaraan Bermotor. Dokumentasi dilakukan dengan cara menumpulkan dokumen-dokumen yang diperlukan yang berupa data target dan realisasi pengujian kendaraan bermotor tahun 2014-2018 dan jumlah kendaraan bermotor tahun 2014-2018. Validasi data dalam penelitian kualitatif merupakan suatu proses uji keaslian data. Menurut (Sugiono, 2016:245 ) menyatakan triangulasi diartikan sebagai teknik pengumpulan data yang bersifat menggabungkan dari berbagai teknik pengumpulan data dan sumber data yang telah ada. Menurut Sugiyono (2017:241) Tujuan dari triangulasi bukan untuk mencari kebenaran tentang fenomena, tetapi lebih pada peningkatan pemahaman peneliti terhadap apa yang telah ditemukan.

\section{Teknik Analisis Data}

Menurut Sugiyono (2017:238) analisis data adalah proses mencari dan menyusun data secara sistemastis data yang diperoleh dari wawancara, catatan lapangan dan dokumentasi, dengan cara mengorganisasikan data ke dalam kategori, 
menjabarkan ke dalam unit-unit, melakukan sintesa, menyusun ke dalam pola, memilih mana yang penting dan yang akan dipelajari, dan membuat kesimpulan sehingga mudah dipahami diri sendiri maupun orang lain. Dalam penelitian ini peneliti menggunakan analisis deskriptif yang digunakan yaitu nilai dari hasil penghitungan laporan penerimaan retribusi pengujian kendaraan bermotor. Data laporan keuangan berasal dari Dinas Perhubungan Kabupaten Ponorogo dianalisis menggunakan rasio efektivitas penerimaan pendapatan asli daerah.

\section{PEMBAHASAN}

Secara keseluruhan pada tahun 20142018 bahwa belum tercapainya pelaksanaan penerimaan retribusi UPT PKB Ponorogo mengalami fluktuatif, Tujuan UPT PKB Ponorogo adalah terwujudnya pelayanan pengujian kendaraan bermotor yang berkualitas, akurat, dan cepat. Tercapainya efektivitas penerimaan retribusi PKB tidak lepas dari aturan UU dan SOP pelayanan yang diberikan petugas $\mathrm{PKB}$ dalam memberikan layanan kepada masyarakat. Berdasarkan hasil wawancara yang telah dilakukan bahwa UPT PKB Ponorogo telah melakukan pelayanan yang berpedoman pada UU Nomor 22 Tahun 2009 Pasal 1 Tentang otonomi daerah yang bertujuan untuk memberikan peningkatan pelayanan dan kesejahteraan masyarakat yang semakin baik,pengembangan kehidupan demokrasi, keadilan, dan pemerataan, serta memelihara hubungan yang serasi antara pusat dan daerah serta antar daerah dalam rangka menjaga kesatuan NKRI. Sejalan dengan tujuan di atas dengan berdasarkan UU Nomor 34 Tahun 2000 dan SOP pelayanan pengujian kendaraan bermotor nomor 551.24/1616/405.22/2017 demi terwujudnya Undang-undang Nomor 33 Tahun 2004 Tentang pendapatan asli daerah yang bertujuan untuk memberikan kewenangan kepada pemerintah daerah untuk mendanai pelaksanaan otonomi daerah sesuai dengan potensi daerah itu sendiri. Namun, pelayanan tersebut belum berpengaruh. Hal inilah yang menjadi UPT PKB Ponorogo perlu mengevaluasi kualitas pelayanan dan SOP yang berlaku hingga saling bekerjasama untuk dapat mencapai target penerimaan PAD pada penerimaan retribusi PKB. Untuk pemberian kemudahan dalam melakukan PKB berbasis Online harusnya terlebih dahulu disosialisasikan bisa melalui media sosial,email, ataupun sosialisasi langsung karena kemungkinan banyak yang tidak tau menganai tata cara registrasi ataupun sistem baru ini. Sehingga masyarakat bisa saling menikmati kemudahan dalam melakukan PKB sehingga penerimaan retribusi $\mathrm{PKB}$ efektif untuk tahun-tahun berikutnya.

\section{KESIMPULAN}

Kesimpulan penelitian ini yaitu :

1. Efektivitas Penerimaan Retribusi Pengujian Kendaraan Bermotor di Kabupaten Ponorogo dalam lima tahun terakhir penerimaan retribusi mengalami fluktuatif sehingga perlu dilakukan upaya pemerintah dalam rangka meningkatkan penerimaan retribusi Pengujian Kendaraan Bermotor di Kabupaten Ponorogo adalah dengan cara memperluas basis penerimaan yang terdiri dari mengevaluasi tarif penerimaan. Pemerintah Kabupaten Ponorogo dalam menentukan tarif penerimaan retribusi sudah sesuai dengan Pergub Ponorogo Nomor 42 Tahun 2016 tentang struktur dan besarnya tarif retribusi pengujian kendaraan bermotor namun dalam pencapaian target penerimaan retribusi pengujian kendaraan bermotor cukup efektif karena pencapaian masih dibawah $100 \%$. 
2. Hambatan-hambatan dalam penerimaan retribusi $\mathrm{PKB}$

Dari segi SDM perlu diperbaiki agar lebih maksimal dalam bekerja sehingga meningkatkan penerimaan retribusi PKB. Diperlukannya sosialisasi agar bersama-sama menjaga keselamatan dalam berkendara. Perlu ditambah Pos pelayanan uji ker yang tidak hanya ada di UPTD sehingga masyarakat lebih mudah menjangjaunya. Memperkuat proses pemungutan, meningkatkan pengawasan, serta memberikan penghargaan yang memadai kepada wajib retribusi yang taat membayar, dan yang belum dilakukan pemerintah dalam upaya ini adalah belum dilakukannya pemberian penghargaan terhadap wajib retribusi yang taat membayar. Meningkatkan efisiensi administrasi pendapatan dan menekan biaya pemungutan adalah menambah drive-thru di Pengujian Kendaraan Bermotor Kabupaten Ponorogo, agar lebih memudahkan wajib uji dalam melakukan PKB dan membayar retribusi Pengujian Kendaraan Bermotor sebagai jasa, tanpa harus datang langsung untuk daftar ke UPTD PKB di Dishub Kabupaten Ponorogo.

\section{DAFTAR PUSTAKA}

Anggraini, Novita Eka., Saifi, Muhamad., Husaini, Ahmad. (2015). Analisis Efektivitas Retribusi Pelayanan Pasar Tanjung dan Kontribusinya terhadap Pendapatan Daerah Kota Mojokerto. Jurnal Perpajakan Vol.1 No.1. Fakultas Ilmu Administrasi. Universitas Brawijaya Malang.

Ayuni, Dessy., Paul, Devid., Elim, Inggriana. (2014). Penerimaan Retribusi Pasar dalam Upaya meningkatkan Pendapatan Asli Daerah Kota Tidore Kepulauan. Jurnal EMBA Vol. 2 No. 2.
Ersita, Elim. (2016). Analisis Efektivitas Penerimaan Retribusi Daerah dan Kontribusinya Terhadap

Peningkatan Pendapatan Asli Daerah (PAD) di Provinsi Sulawesi Utara.

Ersita, Mega., Elim, Inggriana. (2016). Analisis Efektivitas Penerimaan Retribusi Daerah dan Kontribusinya terhadap Peningkatan Pendapatan Asli Daerah (PAD) di Provinsi Sulawesi Utara. Jurnal EMBA Vol. 4 No. 1. Universitas Sam Ratulangi.

Faud, M. Ramli. (2016). Analisis Keuangan Pemerintah Daerah. Bogor: Ghalia Indonesia.

Keputusan Kepala Dinas Perhubungan Nomor 551.24/1616/405.22/2017

Lamia, Alfan., Saerang, David., Wokas, Heince., (2015). Analisis Efektivitas dan Kontribusi Pemungutan Pajak Restoran, Pajak Reklame, dan Pajak Penerangan Jalan pada Pendapatan Asli Daerah Kabupaten Minahasa Utara. Jurnal Berkala Ilmiah Efisiensi. Volume 15 No. 05.

Laporan Keuangan Penerimaan Retribusi Pengujian Kendaraan Bermotor Tahun 2014-2018.

Mahmudi. (2016). Analisis Laporan Keuangan Pemerintah Daerah. Yogyakarta. UPP SKIM YKPN.

Nugraha, Yoga (2019). http://m.detik.com. Peraturan Bupati Ponorogo Nomor 42 Tahun 2016 Tentang Perubahan Tarif Retribusi Pengujian Kendaraan Bermotor.

Peraturan Daerah Nomor 14 Tahun 2011 Tentang Retribusi Pengujian Kendaraan Bermotor.

Pradita, Ferian Dana., Suyadi, Imam., Riza, Muhammad Faisal. (2014). Efektivitas Intensifikasi Pemungutan Pajak Bumi dan Bangunan (PBB) Perdesaan dan Perkotaan serta Kontribusinya terhadap Pendapatan Asli Daerah (PAD) Kota Surabaya. Jurnal. 
Fakultas Ilmu Administrasi.

Universitas Brawijaya Malang.

Sari, Nopiyah (2016). Analisis

Optimalisasi Penerimaan Retribusi

Pengujian Kendaraan Bermotor

pada Dinas Perhubungan Kota

Palembang. Skripsi. Palembang.

Universitas Muhammadiyah

Palembang.

Silalahi (2011), Asas-Asas

Manajemen. Bandung.

Siregar (2015). Akuntansi Sektor

Publik.Yogyakarta.

Sugiyono. (2017). Metode Penelitian

Kuantitatif, Kualitatif dan $R \& D$;

(Cetakan ke 25). Bandung:

Alfabeta.

Sugiyono. (2011). Metode Penelitian

Kombinasi (Mix Methods).

Bandung: Alfabeta.

Undang-Undang No. 23 Tahun 2014

Tentang Pemerintah Daerah.

Undang-Undang No.33 Tahun 2004

Tentang Perimbangan Keuangan

Antara Pemerintah Pusat dan

Pemerintah Daerah.

UU No. 28 Tahun 2009 Tentang Retribusi Daerah.

Widodo.(2017: Analisis Kebijakan Publik; (cetakan ke-10). Malang.

Yuduke,Ayem. (2015). Analisis Efektivitas, Efesiensi Pajak Daerah dan Retribusi Daerah serta Kontribusi Terhadap Pendapatan Asli Daerah di Kabupaten Bantul Tahun 2009-2014. Volume 3. Yogyakarta. 